\title{
Polluter pays? Understanding austerity through debt advice in the UK
}

\section{Ryan Davey}

Ryan Davey is a postdoctoral research fellow at LSE, researching personal debt and class inequality in the UK.r.davey@lse.ac.uk

\begin{abstract}
Taking the case of funding models for free debt advice in the UK, this article argues that the anthropology of austerity has much to gain by asking what survives, or even thrives, under conditions of austerity. Beginning in the 1990s, flows of money from the retail financial industry to free debt advice organizations proliferated, generally upon an identified mutuality of interests between the two. This culminated in the establishment by the UK government of a bank levy in 2012, said to operate on the principle of 'polluter pays', replacing general taxation as the main source of funding for public debt advice. Yet as it stands, the bank levy fails as a potential alternative to austerity because it taxes the institutions that issue debt to the poor at high rates of interest in order to provide the poor with advice that increasingly cannot solve their problems.
\end{abstract}


Going beyond claims that austerity fails as a strategy for macroeconomic growth (Krugman 2015), it is questionable whether policies made in the name of austerity even succeed in reducing public expenditure. Take the recent cuts to social security benefits in the UK as an example. Campaigning organizations claim that the savings generated for local government were outstripped by several unforeseen costs: paying bailiffs to collect people's unpaid council tax and rent and to carry out evictions; paying legal costs to take those with council tax arrears or rent arrears to court; and higher expenditure on housing benefit when those affected by the bedroom tax have been evicted from social housing into more expensive private tenancies. ${ }^{1}$

In this article, I will take these claims further by showing that austerity does not put an end to public expenditure and taxation, but rather brings about new models for revenue-generation and new patterns of public expenditure which together tend to reinforce existing socio-economic inequalities. As well as studying austerity by looking at funding cuts and their unintended consequences (Bear 2015), I contend that there is much to be learned about austerity from looking at how those institutions that escape budget reductions manage to do so. The anthropology of austerity, that is to say, should ask a question that may initially seem slightly perverse: what survives, or even thrives, under conditions of austerity?

\section{Debt advice}

Here, I take the UK's debt advice sector as a case in point, for debt advice was not subject to the same level of austerity cuts as were other forms of social welfare legal advice. In studying debt advice, I focus less on day-to-day advice-giving practices and more on the managerial experiments, policy discourse, business models and funding strategies that enable those advice-giving practices to take place. Doing so enables me to unpack the governmental and managerial logics that arise as responses to shortages in state funding.

In particular, experiments and debates about how to fund debt advice are situated at the very crux of the 'bait-and-switch' that Mark Blyth (2013) observes in austerity rhetoric when the UK government claimed that a crisis caused by financial trading was a consequence of excessive public spending, duly cutting public spending and bailing out the banks. These debates about funding debt advice, then, happen at the point where two policymaking tendencies converge: on the one hand, post-crisis financial governance in the UK which seeks to revive and relegitimize the financial industry; and on the other, the impulse in austerity policy to cut public expenditure from social welfare services.

How would policymakers, debt advice mangers and lenders reconcile a professed scarcity of public funds for social welfare services, such as debt advice, with a recognition that by encouraging people to re-engage with credit markets, debt advice often serves the interests of the financial industry? Studying this convergence reveals that the health of the financial markets was prioritized at the direct expense of redistribution. The material on which I draw comprises documentary research using policy reports, interviews with senior debt advice staff and participant observation at local debt advice centres in the south of England. I discuss changes to how debt advice is funded, at the level of management and policy-making, before studying the effects of these changes on everyday advice-giving practices.

To give some background to the field of practice under study, free-to-client debt advice emerged in the 1980s alongside the expansion of consumer credit in the UK. ${ }^{2}$ People contact or visit a debt advice centre when they cannot pay what their creditors are demanding; this includes financial debts like loans and credit cards, but also non-financial debts such as water arrears, council tax arrears and rent arrears. The debt adviser assists the client to work out how much she owes and to whom and then to pay her creditors by helping her to economize or negotiate lower repayments with the creditor. Alternatively, the adviser may help the client to go insolvent. In practice, much of the work of debt advisers also involves persuading the more disaffected clients to recognize their debts as moral obligations (Kirwan 2016).

Rising levels of consumer debt in the UK are linked to austerity in complex ways. Cuts to state spending on social welfare, such as public housing and social security benefits, along with the UK government's growing 
reluctance to invest in industry and infrastructure, have created a generalized kind of economic insecurity, which includes precarious work, stagnating wages, benefit sanctions and insecure tenancies. This has led many people to rely on borrowing merely in order to subsist (Standing 2009).

Debt has thus become a flawed substitute for the 'safety net' once provided by the mid-century welfare state (Montgomerie 2013). Though 'austerity’, in so many words, began in Britain in 2010, these earlier neoliberal policies of reducing social expenditure were nonetheless geared towards servicing sovereign debt obligations - the 'new public good' that Laura Bear (2015) identifies as the kernel of austerity policy. ${ }^{3}$

The increased supply of consumer credit, not just the demand for it, is also related to austerity. Sovereign debt bonds to commercial banks proliferated in the 1990s, informed by what is known as the 'state starvation thesis' - the claim that capital is more productive in private rather than public ownership (see Bear, this issue). By issuing sovereign debt bonds and so acquiring repayment obligations to commercial banks, the Bank of England effected a transfer of capital from the state to the commercial banking system, who could now trade on their expectation of receiving payments from central banks. This partly fuelled the growth of financial derivatives trading which further increased the capital with which commercial banks could speculate by lending to ordinary people.

Lenders were motivated to cast their nets wider in this way by both the invention of financial instruments such as asset-backed securitization that enabled them to measure, manage, and speculate on the uncertainty of borrowers defaulting (Langley 2009), ${ }^{4}$ and by Thatcher's removal of the cap on interest rates (Deville 2015). The costs of these changes were concentrated among lower income groups, whom lenders tend to identify as 'riskier' and therefore subject to higher rates of interest (Langley 2009). Hence, the reproduction of socioeconomic inequality is built into this model of 'risk-based pricing' for credit (ibid.). As a result of these financializing processes - at both personal and state levels - the extraction of rents in debt relations has displaced the exploitation of productive labour as the 'centre of gravity' of class-based economic extraction today (Graeber 2012: 75).

Recent changes in the funding of debt advice in Britain may be interpreted in the light of the above. Until the recent period of government austerity, there were three main funders of free, public debt advice: local authorities, Legal Aid and the Financial Inclusion Fund, with their funds sourced from general taxation. Since 2010, the UK has seen massive cuts to Legal Aid and local government funding, leading to many redundancies and advice centres closing. The Financial Inclusion Fund, however, was not so affected as it was transferred in 2012 to a new quasi-autonomous body called the Money Advice Service. But, while the level of funding stayed the same, its derivation changed from general taxation to a levy on the financial industry known as the bank levy. Crucial to the story of how debt advice sources its funds, then, is the growing practice of deriving funds from lenders.

Here I approach the question of austerity by discussing two different ways in which providers of free debt advice have obtained funding from the lenders: first, through 'fair share' contributions from creditors; second, from the aforementioned bank levy, which is said to work on a 'polluter pays' principle. This model of taxation - an industry-specific levy, channelled towards offsetting the harms that industry produces - is one of the ostensible 'alternatives to austerity' this article explores. Yet it is a self-defeating alternative, for as I will show, it taxes the agencies that lend to poorer people at high rates of interest in order to give those same people advice that is increasingly redundant.

\section{Giving their 'fair share'}

In the 1990s, a claim emerged that would become dominant across the sector: that debt advice could serve lender and debtor interests at one and the same time. It originated among debt advice agencies experimenting with non-state-dependent models of revenue generation. One of these models, known as 'fair share' contributions, is employed by several debt advice organizations, including PayPlan, StepChange and 
Christians Against Poverty. ${ }^{5}$ While the latter two are registered charities, PayPlan is a profit-making business that was set up in 1992 and provides debt advice with no charge to the client, ostensibly giving the same service as a public or voluntary sector institution. The 'fair share' contribution model it follows comprises an agreement with major lenders that for every payment a lender receives from a client of PayPlan, that lender will pay PayPlan around 10 per cent of what they received - its 'fair share' of the repayment it has helped to bring about.

PayPlan itself states that it provides an impartial advice service to clients in a sustainable way. However, its critics say it is merely a 'cash collection service' for creditors, thereby inverting the service's notional beneficiary: i.e. the creditor, rather than the person in debt. These critics say PayPlan's business model affects its ability to be impartial because its advisers set clients up on repayment arrangements that, if they fail, can be disastrous for the client, but inflict no cost on PayPlan itself.

\section{The bank levy}

Since 2012, mutual interests between the debt advice sector and the financial industry have been identified on a much larger scale, with funds for a new national Money Advice Service being derived from a levy on financial corporations. This principle for deriving funds from creditors has been termed 'polluter pays'. It emerged after the Coalition government's announcement of a programme of austerity in 2010, heralded by David Cameron as an 'age of austerity', with the aims of curbing wasteful government spending and bringing about 'fiscal responsibility' ${ }^{6}$

The Tory-led government argued that excessive public spending by the previous Labour government was the cause of the UK's present economic troubles. Consequently, in 2011, the government said it would axe debt advice funding, leading to widespread alarm across the sector about redundancies and abandoned clients. ${ }^{7}$ In April 2012, however, the government announced that instead of axing the public provision of debt advice altogether, it would set up a new organization called the Money Advice Service which would commission debt advice services across England and Wales. It had an unusual source of funding: instead of general taxation, it would be funded by a new levy imposed on the financial industry by the regulator, the Financial Conduct Authority. This became known as the bank levy.

The then chancellor, George Osborne, brought in this measure on the recommendation of the International Monetary Fund (IMF), as a 'financial stability contribution'. The IMF had recommended to the G20 that governments tax the liabilities held by all banks in order to disincentivize risky lending (Boyle 2015; International Monetary Fund 2010). The tax was also intended to raise funds that could offset the future costs of the systemic risk to the economy generated by the liberalized financial industry. The IMF proposed that governments put these funds away for a rainy day, such as the next bank bailout or financial crisis. The UK government, however, modified the IMF's proposal by channelling the funds straight into the Treasury.

With the announcement that the Money Advice Service would be funded by this new levy, a new principle emerged for the funding of public services which its advocates called 'polluter pays' (Gillespie \& Dobbie 2009: 47). Reflecting its hybrid public-private status, the head of debt advice at the Money Advice Service, Caroline Siarkewicz, told me the new funding represented 'a massive shift away from public funding to, well, arguably the levy is vaguely public funding but it’s not raised through taxation in the same way'. I asked her:

R: Could you call it a 'polluter pays' kind of principle?

C: Exactly, that phrase is used quite a lot these days around debt advice.

The bank levy's critics consider it tokenistic: they say the principle is great, but the amount it generates is puny (Boyle 2015). Nonetheless, it benefits the anthropological understanding of austerity policy to elaborate the governmental logics therein (Bear 2015). With the 'polluter pays' principle, a 'harm industry' (Benson \& Kirsch 2010) is called upon to offset the new and continuing harms it causes by providing the funds for a public service designed to alleviate those harms. The 'polluter pays' principle thus applies a logic of offsetting 
to the resourcing of social welfare, whereby funds for a public welfare service are not sought from general taxation but instead from the industry responsible for the harm that the service seeks to address. Through the bank levy, the financial services industry would, so it went, offset the harms of over-indebtedness and economic insecurity that its everyday operation generated. Amid intense public criticism this mitigation fee would bring about the industry's redemption.

While first mooted in 1992 (National Consumer Council 1992), the idea of a statutory levy on banks to fund advice only gained traction following the recent financial crisis, when it was resuscitated in policy documents stating expectations of imminent austerity cuts to state funding (Gillespie \& Dobbie 2009). 'Polluter pays' as a tractionable principle for resourcing social welfare in Britain was, therefore, an unforeseen consequence of austerity discourse, testifying to the political success of the claim of scarce public funds.

Policy discussions have recently proposed that the principle be extended by reconsidering 'who to count as a polluter' (The Low Commission 2013: 6). In 2015, the government (Farnish 2015: 26-27) accepted a proposal that since a post-crisis contraction in lending had led to a rise in non-financial debts owed to utility companies, phone companies or central or local government, then 'a wider body of creditors (i.e. not just the financial industry) should be contributing to the funding of money and debt [advice]' (The Low Commission 2014).

'Polluter pays' is one way of conceptualizing this flow of money from creditors to debt advice providers. But another framing emerged alongside it. The bank levy was also justified on the basis that debt advice serves the economic interests of the credit industry. The government's review of the Money Advice Service, for instance, said: 'customers tak[ing] expert advice can lead to increased levels of debt recovery, lower bad debt write-off levels ... reduced costs associated with chasing arrears, and reduced costs of debt collection and enforcement' (Farnish 2015: 15).

The two framings for the bank levy - a remedy for a harm and a payment for a cash collection service - sit curiously cheek by jowl. For instance, in an early proposal for lender-funded advice, in 1988 the minister for corporate affairs said 'it is not only part of the responsibility of the private sector but very much in its commercial interest to provide support for money advice services' (quoted in National Consumer Council 1992).

Similarly, many Money Advice Service publications, along with much commercial and voluntary sector lobbying around debt advice, has emphasized that debt advice benefits ordinary debtors and the credit industry at once (Accenture \& British Bankers Association 2010; London Economics 2011). The degree to which these two logics for the bank levy sit side by side suggests that the financial industry's responsibility for remedying its harmful effects might extend only as far as it is profitable.

\section{Advice-giving under austerity}

The Money Advice Service has trumpeted its increases in 'efficiency'. Its head of debt advice, Caroline Siarkewicz, told me: 'We’ve gone from helping 160,000 people [a year] when we took it on, to 425,000 in the [financial] year that's just started [2016/17]'. However, it has been highly unpopular with 'front-line' advisers. One advice manager told me: 'You are unlikely to meet a happy Money Advice Service case worker anywhere in the UK', due to its prescriptiveness and higher caseload requirements. This transfer of the main stream of funding for debt advice from one based on general taxation to one based on the principle that debt advice serves lenders' and debtors' interests at once, has led, ironically, to increasing frustrations among front-line advisers about not being able to serve their clients' interests. Yet, while many advisers have become vocal critics of how austerity policy is failing their clients, others have instead attributed the frustrations of their job to failings with the clients themselves.

These advisers, acquiescing to the changes wrought by 'polluter pays' funding, seem to have projected the frustrations of working under these new arrangements onto their clients. At a debt advice charity in the south 
of England that I visited during fieldwork in 2013, the advent of Money Advice Service funding saw caseload targets surge by 60 per cent and rendered the advisers' continued employment conditional upon meeting those targets.

One of the advisers there, a man named Bernie, usually attributed his clients' debt problems to individual financial mismanagement or a lack of 'financial skills', echoing the ethos of widespread financial education programmes. He often complained about his clients' profligacy and welfare dependency, mentioning how much they spent on flat-screen TVs ('they’ve all got them'), alcohol or unlicensed tobacco. Yet his ascription of individual moral responsibility to clients for their over-indebtedness was also embedded within the bureaucratic procedures and documents of the advice service itself.

Because his clients usually did not know (or had disregarded) how much they owed and to whom, the bulk of Bernie's day-to-day work lay in compiling a list of their debts on a form called the Common Financial Statement. He would then calculate a plan for the clients to progressively clear their debts through monthly repayments. Because the aim was to purge debts entirely rather than merely service them, each enumerated debt became a moral index of the client's responsibility to repay in full. ${ }^{8}$

When his caseload targets rose in 2013, Bernie adapted his working practices, telling me 'you have to be creative' and to 'play the numbers game'. This included counting brief exchanges as full cases and increasingly favouring Debt Relief Orders (DROs) - a form of insolvency for people on low incomes because they were quicker and suited most of his clients. ${ }^{9}$ But his adaptations elicited criticism from his managers about the service becoming a 'DRO factory', mass-produced rather than tailored and flexible. Bernie and his manager disagreed about how best to serve their clients’ interests.

Bernie justified these tactics by emphasizing 'empowerment' as a virtue in advice-giving. He explained that clients would not benefit in the long term were one simply to 'wave a magic wand and make it all better'. What was more, he added, appointments could be done more quickly 'if you don't feel like you have to do everything for them'. Empowerment also saved money: 'I very rarely send letters to creditors. The stamps would cost thousands. And that's an empowerment again, if the client rings up their creditors instead. That's the ethos of the Money Advice Service'. ${ }^{10}$ I asked Bernie if this emphasis on empowerment was about justifying funding cuts. He said: 'I’ve always said, if we don't empower clients, then something's going to force us to. It can be compared to the benefits system. Why should people who do it for themselves be worse off than those who rely on others?'

Bernie initially responded to the shift to Money Advice Service funding, and the subsequent precarity of his own employment, by commenting on the difficulties created by a lack of available jobs, increased cost of living and cuts to welfare benefits. Yet his increasing reliance on the notion of empowerment meant an occasional refusal - borne out of an unprecedented caseload - to confront the extent of some clients' difficulties. Should a client become unresponsive or fail to carry out the actions delegated to them, then the case would eventually be dropped. Bernie’s 'numbers game' and 'empowerments' together expanded the realm of possible failures on the part of the client. As his clients' perceived faults became the screen onto which he projected the increased frustrations of his job, Bernie quietly reconciled himself with the pressures of austerity.

Other debt advice representatives, by contrast, have expressed a palpable anger arising from their frustrated desire to assist their clients. They count among the most vocal critics of Money Advice Service funding and austerity as a whole. While none of them spoke to me about the question of whether advice can serve clients' and lenders' interests at once, it was clear that they felt clients' interests were not being met. Indeed, they wrestled with questions about what real alternatives to austerity might be possible.

At a recent public lecture at LSE featuring advisers, activists and academics working on debt (Bear et al. 2017), Carl Packman from the debt advice charity, Toynbee Hall, said that beyond funding cuts, the wider 
effects of austerity and financialization 'affect the client of debt advice to the degree where [the sorts of] advice [given are] becoming increasingly redundant'. Carl recounted a colleague asking him what possible advice he could give to 'someone who has already budgeted and cut down on things and stopped paying essential bills?' He said that publicly funded debt advice could no longer solve the problems of such people. As a result, he called on debt advisers to consider advocating debt refusal and debt cancellation, as have other organizations such as the New Economics Foundation.

At the same event, Peter Tutton from StepChange said that while major debt advice charities had secured 'technocratic' improvements for over-indebted people, policymakers were averse to reducing levels of structural inequality. Echoing Bear's (2015) argument that austerity policy foregoes a concern with redistribution as a social good, he said: 'What we're unsuccessful in doing is [addressing] questions about distribution. And yet with financialization, we are dealing with a change in the way that distribution happens and widening inequality. That seems to be taboo in the policy discussions, even around poverty. So how do we get it on the political radar?'

\section{Conclusion}

As I have shown, in the case of UK debt advice, 'austerity' did not entail an end to public spending and taxation. Instead, it gave rise to new models of taxation and public expenditure, premised on offsetting the harm an industry does. Yet this principle was generally subordinated to a paradoxical claim that debt advice serves both the interests of those harmed by that industry and the commercial interests of that industry at one and the same time. The irony of this claim, as a basis for funding, is that the advice thereby funded has become increasingly redundant for those it is meant to help. As it stands, the bank levy fails as a potential alternative to austerity because it taxes the institutions that issue debt to the poor at high rates of interest in order to provide the poor with advice that increasingly cannot solve their problems.

Debt advice was not subject to quite such drastic cuts as other areas of social welfare advice; cuts to debt advice, therefore, were tempered by other concerns and means. To grasp what these might be, one must see the bank levy within the broader context of the British state's relation to the financial industry, chiefly its bailout of the banks in 2008/9 and the 'bait-and-switch' (Blyth 2013) that soon followed.

There is a revealing symmetry between the government's decision to impose a levy on financial corporations for the sake of disincentivizing risky lending and its decision to channel the funds thereby raised towards assisting people who have fallen foul of their lenders. As an act of financial governance, the bank levy followed the government's bailout of the banks, initially to mitigate having to bail them out again in future. The sense that banks were now contributing to macroeconomic stability contributed to their public relegitimation. The public provision of debt advice can be viewed as an act of financial governance too, in that by assisting ordinary people to continue to participate in consumer credit markets (through continued repayments and salvaging their credit ratings) or, alternatively, to opt out of them (as with insolvency), debt advice facilitates the ongoing functioning of those markets (Walker et al. 2015).

Moreover, debt advice often legitimizes the operation of retail financial markets by coupling the legal obligation to repay a debt with a sense of individual moral responsibility, whether by encouraging debtors to honour their debt obligations or by guiding them through the still somewhat punitive procedures for insolvency. As I have shown, the pressures of austerity, in some cases, lead advisers to intensify their ascriptions of moral fault to their indebted clients. This echoes what Goriely calls the 'ideological benefits' (1996: 242) of providing legal advice to the poor. In other cases, though, advisers have reflected on how structural conditions are preventing them from assisting their clients in meaningful ways. In search of alternatives to austerity, some advisers now advocate debt refusal, while others are challenging a taboo on redistribution in policymaking circles. 
I have shown that debates and experiments about how to fund debt advice are situated at the crux of the 'bait-and-switch' Blyth (2013) observes in austerity rhetoric. They highlight a contradiction between two tendencies in contemporary UK policymaking: first, pinning the welfare of society on the proper functioning of financial markets (Langley 2015); second, cutting public expenditure from social welfare services, which we know as austerity. With the establishment of the bank levy as a funding stream for debt advice, austerity as an approach to social welfare provision was tempered by post-crisis financial governance. What is more, when seen in the context of the two aforementioned legitimating moves - redeeming banks for their riskiness and confirming the moral fault of defaulting debtors - the 'bait-and-switch' of austerity rhetoric is but one contributor among several to the moral-ideological resuscitation of liberalized financial markets in the wake of those markets' crisis.

While 'austerity' usually refers to cuts to social welfare, we should take the term as a mere point of departure. For what anchors those funding cuts is another set of processes whereby states have transferred capital to the private banking system and made sovereign debt servicing a political priority at the expense of redistribution (Bear 2015). This same set of processes has not only led to the expansion of consumer lending at 'risk-based' rates of interest that reproduce existing inequalities, but it also lies at the heart of generating the very problems that debt advice nominally sets out to remedy - economic insecurity, precarious income or tenure and using high-interest credit for subsistence.

Therefore, as long as providing support and relief to over-indebted people remains secondary to sovereign debt repayment as a political aim, these problems and this regeneration of inequality is likely to continue. Challenging the moral belief that you must always repay your debts, no matter what, and bringing the distribution of wealth and resources back into political conversations, as some debt advisers have begun to do, look like rare, robust alternatives.

\section{Notes}

1. See: http://blog.shelter.org.uk/2014/08/repossessions-are-up-is-the-bedroom-tax-to-blame/; http://shelterpolicy.wpengine.com/2014/07/thebedroom-tax-by-numbers/; https://www.jrf.org.uk/report/housing-benefit-size-criteria-impacts-social-sector-tenants-and-options-reform; https://www.jrf.org.uk/report/impact-welfare-reform-social-landlords-and-tenants.

2. For a historical account of legal advice to poorer people in the UK, including debt advice, see Goriely (1996).

3. It is perhaps worth distinguishing neoliberal and austerity policies analytically. They often lead to the same sorts of measures, reducing the social or redistributive functions of the state. Both also feature a sense that there is 'too much state'. So they are better distinguished in terms of the way policies are justified; namely, that neoliberalism features claims that people can best prosper through the state stepping back and austerity features a sense that the state has spent too much and must tighten its belt. In Britain, these two sets of justifications for reducing state spending on welfare often sit side by side: for instance, reductions in welfare benefits since 2010 have been justified both as a means of providing the necessary encouragement to benefit claimants to find fulfilling work, and as a result of the government having irresponsibly spent too much on them. This example shows we should be wary of assuming too much coherence or self-consistency in the way that government reforms are reasoned.

4. The invention of asset-based securitization in the 1980s made payment streams profitable not merely for the actual payments in themselves, but moreover for the value of being able to expect payments in the future. This expectation then became a tradeable commodity (Langley 2009). Consumer lenders massively expanded their lending activities by trading their assets (their expectation of receiving repayments) with investors. They expanded further still due to the invention of 'structured' financial instruments like collateralized debt obligations that enabled assets of varying risk levels to be packaged in one product (ibid.).

5. Another model, known as 'partnerships', works on a similar basis though more like a charitable donation. The chair of a Citizens Advice Bureau who had been establishing several partnerships with creditors wrote that success in obtaining funding through partnerships came from identifying 'a mutuality of interests' between debt advice organizations and the various creditors to whom people owe money (Guy 2013).

6. See: https://www.theguardian.com/politics/2009/apr/26/david-cameron-conservative-economic-policy1.

7. See: https://www.theguardian.com/money/2011/feb/01/debt-advice-funding-axed; https://www.theguardian.com/law/2011/jan/21/financialinclusion-fund-cuts.

8. This supports Walker et al.'s (2015: 251) claim that financial statements in debt advice discipline debtors by validating their debts.

9. Debt Relief Orders are a form of insolvency created by parliament in 2009 as an alternative to bankruptcy. They are available only to those without assets over $£ 300$ and whose debts total no more than $£ 20,000$. A debtor has to pay a fee of $£ 600$ for bankruptcy, whereas for Debt Relief Orders the fee is $£ 90$.

10. The Money Advice Service's reduction of funding and drive for greater efficiency in debt advice featured a promotion of 'financial capability' which sought to enable clients to take responsibility for their situations (see e.g. Elliott et al. 2010). 


\section{References}

Accenture \& British Bankers Association 2010. A new model for dealing with personal debt. London.

Bear, L. 2015. Navigating austerity: Currents of debt along a South Asian River. Stanford, CA: Stanford University Press.

— et al. 2017. Austerity, debt - What alternatives? LSE Works Public Lecture, 1 March. http://www.lse.ac.uk/websitearchive/newsAndMedia/videoAndAudio/channels/publicLecturesAndEvents/player.aspx?id=3768.

Benson, P. \& S. Kirsch 2010. Capitalism and the politics of resignation. Current Anthropology 51(4): 459-486.

Blyth, M. 2013. Austerity: The history of a dangerous idea. New York: Oxford University Press.

Boyle, C. 2015. George Osborne’s permanent bank levy - Is it seignorage? Positive Money Blog, 25 September.

Deville, J. 2015. Lived economies of default: Consumer credit, debt collection and the capture of affect. New York: Routledge.

Elliott, A. et al. 2010. Transforming Financial Behaviour: Developing Interventions That Build Financial

Capability. London: Consumer Financial Education Body.

https://www.moneyadviceservice.org.uk/files/research_jul10_cr01_full_report.pdf.

Farnish, C. 2015. Review of the Money Advice Service. London: HM Treasury.

Gillespie, M. \& L. Dobbie 2009. Funding money advice services: Exploring sustainable models for the UK. Dorking: Friends Provident Foundation.

Goriely, T. 1996. Law for the poor: The relationship between advice agencies and solicitors in the development of poverty law. International Journal of the Legal Profession 3(1/2): 215-248.

Graeber, D. 2012. Dead zones of the imagination: On violence, bureaucracy, and interpretive labor. The 2006 Malinowski Memorial Lecture. HAU: Journal of Ethnographic Theory 2(2): 105-128.

Guy, J. 2013. Partnerships working in money advice. Quarterly Account, Summer.

International Monetary Fund 2010. A fair and substantial contribution by the financial sector. Final report for the G20.

Kirwan, S. 2016. The UK Citizens Advice service and the plurality of actors and practices that shape 'legal consciousness'. The Journal of Legal Pluralism and Unofficial Law 48(3): 461-475.

Krugman, P. 2015. The austerity delusion. The Guardian, 29 April.

Langley, P. 2009. The everyday life of global finance: Saving and borrowing in Anglo-America. Oxford: Oxford University Press.

— 2015. Liquidity lost: The governance of the global financial crisis. Oxford: Oxford University Press.

London Economics 2011. Funding debt advice in the UK - a proposed model. London: Money Advice Service.

Montgomerie, J. 2013. America’s debt safety-net. Public Administration 91(4): 871-888.

Muller, P. et al. 2012. Debt advice in the UK: Final report for the Money Advice Service. London: London Economics.

National Consumer Council 1992. Funding money advice services: A statutory levy on the credit industry. London.

Standing, G. 2009. Work after globalization: Building occupational citizenship. Cheltenham: Edward Elgar Publishing.

The Low Commission 2013. Context paper on debt. London.

— 2014. The future of money advice. 4 September. http://www.lowcommission.org.uk/Blog/The-Future-of-Money-Advice.

Walker, C. et al. 2015. Parasitic encounters in debt: The UK mainstream credit industry. Theory \& Psychology 25(2): 239-256. 